\title{
Assumptions for Including Organic Food in the Gastronomic Offering of Istrian Agritourism
}

\author{
Pavlo Ružić*
}

Ivana Medica**

Received: July 2009 | Accepted: September 2009

\section{Abstract}

The authors of this research analyse assumptions to including organic food in the gastronomic offering of Istrians agritourism. They assume that gastronomic offering of Istrian agritourism that includes organic food would be more acceptable and competitive on the tourist market.

The authors analyse their assumptions using surveys conducted in 2007 and 2008 on tourists in Istra to learn whether they prefer organic food, does organic food match modern tourist trends, and are they willing to pay more for it.

Key words: organic food, gastronomic offering, agritourism, tourist market.

\section{Introduction}

The latest tourist surveys point to a growing interest in nature, especially in nature that is ecologically pure. This is accompanied by a growing interest for holidays in agritourism establishments with organic farming. Taken in the context of what has been said above, this is a trend that calls for making organic food a part of the gastronomic offering.

Organic food is more expensive than conventional food, and it is not easy to come by. Regardless of higher cost and scarcity, there is a preference for organic food for reasons of health, as well as for the following six, additional reasons:
1. no pesticides
2. no growth hormones
3. no antibiotics
4. no irridation
5. no effluents
6. no GMOs (www.zemljani.com/forum/viewtopic.php).

\footnotetext{
* Institute of Agriculture and Tourism, Poreč, pavlo@iptpo.hr

** Teacher Training College, Zagreb, medicaivana@gmail.com
} 
Tourists today are increasingly becoming aware of, and taking responsibility for, their health. They are willing to do more and more for their health to prevent illness. However, the level of their awareness and responsibility has not yet peaked. This means that concern for one's health is an on-going trend, and catering establishments in rural tourism are expected to adapt their offerings to include health food, as an element of health.

Increasingly, tourists are becoming better informed about the methods of food production, gene manipulation, and the impact that food has on health. That is why, today, meeting the basic needs of tourists is no longer enough, because such an approach does little to motivate them. Tourists should be offered added value such as enhanced taste of food, controlled hygiene of production, food safety, reusable packaging, and a method of production that has a less negative impact on the environment.

According to the research of Davies et al. (1995), organic food is perceived as food free of "chemicals" and "growth hormones", food that is not treated, and food that is "natural". Organic (biological, ecological) food is food whose production is based on ecological principles (avoiding the use of artificial chemical agents, such as artificial fertilisers, pesticides, additives, medical products, etc.). Its goal is to achieve a sustainable agricultural system. In agriculture, it places the greatest emphasis on environmental and soil protection, and in animal rearing, on concern for the well-being of animals.

Today, the demand for organic food is steadily growing. World demand for organic food is growing at an annual rate of $20 \%$ (Squires et al., 2001) Retail sales of ecologically produced food were expected to exceed 82 billion USD by 2008 (Arvanitoyannis \& Krystallis, 2004). The production of organic food and its presence on the Croatian market area also continue to grow. However, the number of eco-producers in Croatia is still too few to enable the formation of a marketplace based on domestic production (Radman, 2005). The concept designed in this paper seeks to help build a marketing system for the organic food offering, a system that is poorly developed in both Croatia and Istria.

\section{Research methodology}

The paper examines the expediency of including organic food in the gastronomic offering of Istria's agritourism. The key elements of research involve the consumer habits of tourists in Istria regarding organic food, their attitudes towards the consumption of organic food, their level of interest in consuming organic food, and their willingness to pay more for organic food. Also, the paper looks at how trendy organic food is and which programs could become a part of the gastronomic offering of agritourism is Istria.

These key elements were examined based on primary and secondary sources of data obtained using the survey method and statistical processing. In Istria, surveys were conducted over two consecutive years: in 2007 and 2008, when, respectively, 600 and 1300 tourists were surveyed.

The profile of surveyed tourists is complex and includes all tourist patterns, in the high seasons and off-seasons, and other customary features such as sex, age, education, nationality and monthly income. Given the inclusion of these factors, the group of surveyed tourists matches the structure of visitors to Istria.

The data gathered and research results obtained were used to test the hypothesis stating that, when complemented with ecologically prepared food, the gastronomic offering of agritourism in Istria becomes acceptable and competitive on the tourist market. 


\section{Research results}

The research results selected and illustrated below are the results that provide the best support to the marketing concept analysed in this paper and that adequately make a case for the formulated hypothesis. These results are used to identify the habits of tourists in consuming organic food and to assess the existing condition of the offering, the interest of tourists in organic food, and their willingness to pay more for organic food. They also analyse current trends in nutrition, as well as special programs for introducing organic food in the gastronomic offering of agritourism in Istria.

\section{Habits of Istrian tourists in consuming organic food}

The research conducted has confirmed that tourists visiting Istria have already acquired habits when it comes to purchasing and consuming organic foods. For example, the 2008 survey of the Institute of Agriculture and Tourism, Poreč established that over $63 \%$ of the tourists surveyed do buy organic food in their home country. Table 1 illustrates the places and facilities in which they usually purchase organic food at home.

Table 1: Places at home where inbound tourists buy organic food

\begin{tabular}{|r|l|r|}
\hline & \multicolumn{1}{|c|}{ Place (facility) } & Responses in \% \\
\hline 1 & Specialised shops & 51.46 \\
\hline 2 & Market-places & 46.93 \\
\hline 3 & Other shops & 35.60 \\
\hline 4 & Directly from producers & 23.95 \\
\hline 5 & Other places & 3.56 \\
\hline 6 & Specialised restaurants & 1.29 \\
\hline 7 & No response & 0.97 \\
\hline
\end{tabular}

Source: Survey of the Institute of Agriculture and Tourism, Poreč, 2008

The responses of the greatest number of tourists show that at home they buy organic food in specialised shops, market-places and directly from producers. Data in Table 1 also indicate that some tourists consume organic food in restaurants, but these are in minority. The

Table 2: Places in Istria where tourists would like to buy organic food

\begin{tabular}{|c|l|r|}
\hline & \multicolumn{1}{|c|}{ Place (facility) } & \multicolumn{1}{|c|}{ Responses in \% } \\
\hline 1 & In the hotel where they are staying, as part of the hotel's gastronomic offering & 58.93 \\
\hline 2 & In local shops & 31.55 \\
\hline 3 & In restaurants, as part of the menu & 29.17 \\
\hline 4 & At market-places & 22.92 \\
\hline 5 & In specialised restaurants & 9.82 \\
\hline 6 & In the shop of the motor camp where they are staying & 9.23 \\
\hline 7 & Other places & 2.38 \\
\hline 8 & No response & 1.79 \\
\hline
\end{tabular}

Source: Survey of the Institute of Agriculture and Tourism, Poreč, 2008 
2008 survey established that $70 \%$ of tourists surveyed are interested in buying and consuming organic food in Istria. Their responses as to where they would like to buy organic food in Istria are listed in Table 2.

The responses of the majority of tourists surveyed indicate that they are interested in consuming organic food in Istria and are willing to buy it especially in the hotel where they are staying, 31.55\% of surveyed tourists are interested in buying organic food in local shops and $29.17 \%$ of them want to tray in restaurants, as part of the menu. Just $1.29 \%$ of tourist consume organic food in restaurants at home but $9,82 \%$ of surveyed tourists want to go in that restaurants during vacation.

\section{The offering rate and tourists interest in ecologically produced food in Istria}

Survey made by Institute of Agriculture and Tourism, Poreč, 2007., presents the attitudes of tourists regarding the organic food offering and their interest in this type of food. The surveyed tourists gave responses to questions; how they see the organic food offering and how interested they are in this type of food: Results are: $19 \%$ responded that the organic food offering in Istria is insufficient; $55 \%$, that they are interested in organic food; and $26 \%$, that they are not organic food-oriented.

Institute of Agriculture and Tourism, Poreč, in 2008 made survey on tourist to understand tourists interest for organic food in Istria. According to that results, the $45-54$ age group, accounting for $27.38 \%$ of surveyed tourists, displayed the greatest interest in organic food.

The fact that $60.10 \%$ of the surveyed female population expressed an interest in organic food confirms that the female tourist population is more interested in organic food than the male population.

Tourists holding college and university degrees showed the greatest interest in organic food $(52.02 \%)$

An analysis of the level of interest displayed in organic food by tourists to Istria as per occupation reveals that office employees (29.43\%) show the greatest interest in this type of food.

Tourists belonging to higher income brackets show a greater interest in organic food.

Tourists staying at hotels carrying four or more stars show a greater interest in organic food. A survey conducted in Spain also shows that tourists spending their holidays in threestar, four-star and five-star hotels have a greater interest in organic food (30\% of tourists surveyed) (Fernandez et al., 2003).

By analysing the attitudes and interest of tourists in organic food, it is evident that while tourists visiting the Istria tourist destination show a greater interest in organic food, the offering of organic food itself is very limited. The survey conducted demonstrates that tourists to Istria accept organic food and, as such, it should be included in the gastronomic offering of both its coastal and rural areas in agritourism.

\section{Tourists willingness to pay more for organic food}

Tourists to Istria, surveyed in 2007 , demonstrated that not only are they interested in organic food, but also they are also willing to pay more for it.

Interestingly, $52 \%$ of tourists surveyed are willing to pay as much as $10 \%-15 \%$ more for organic food. The fact that $8 \%$ of tourists surveyed would be willing to pay even more $(20 \%$ - 
$30 \%)$ is also noteworthy. This, again, indicates the need for offering high-quality organic food, because quality enables higher prices and leads to recommendations.

Today, the trend in tourism is focused on the "health industry" with nutrition and food being an exceptionally vital segment. Hence, if tourists who are staying in Istria are prepared to pay more for healthy food, the question remains: Why is more not being done to provide such products?

\section{Including organic food as a part of agritourism gastronomic offering}

These specialised agritourism establishments are classified as "BIO". They are intended for guests who opt for an organic or bio diet. As a rule, such guests have high criteria and expect an ecological approach not only to production, but also to all other activities within an agritourism establishment. In these establishments, rooms are furnished used natural materials, and pots and pans for food preparation are made from the same materials used in the past. The establishments are also expected to use alternative energy sources. Waste must be sorted and organic waste, used for composting. All meals are prepared according to the principles of a rational diet. As a rule, guests arrive at these agritourism establishments either by public transportation or by horse carriage.

The underlying idea of these agritourism establishments is "to show young people from the city about life and work in organic farming, and to contribute to their environmental education". Based on this idea, an offering has emerged that focuses on understanding nature. Vis-

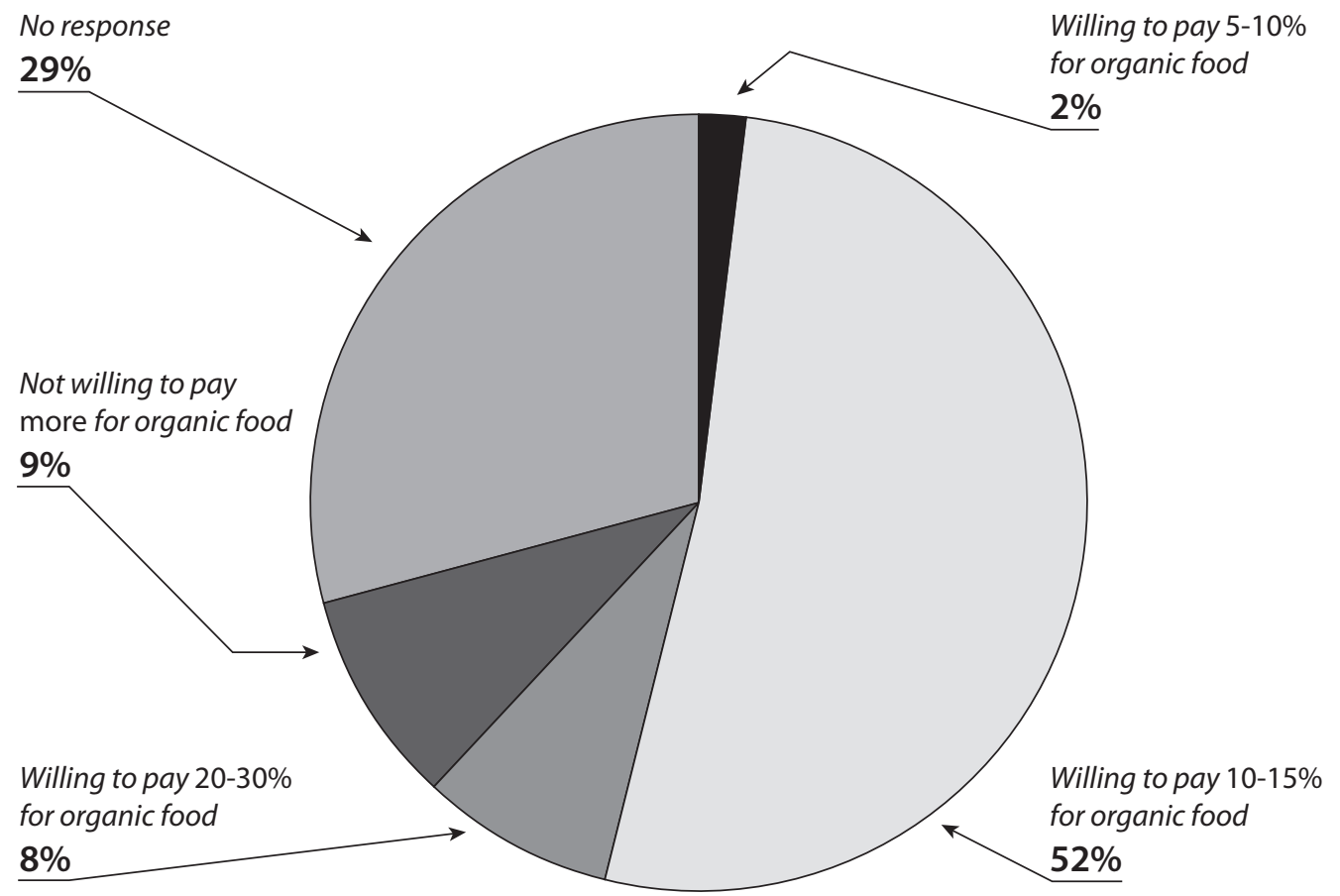

Figure 1. Attitudes of tourists towards paying more for organic food Source: Survey of the Institute of Agriculture and Tourism, Poreč, 2007. 
itor target groups are teachers and students, who show a particular interest in ecology. Oneweek stays have already been included in the curricula of some Austrian schools. This offering involves the following:

- learning to bake whole grain bread and buns

- learning to make sauerkraut

- milking using a milking-cow model to ensure safety

- milking contests

- helping to feed the animals

- milk separation and making butter

- taking a hay ride in a horse-drawn wagon

- planting, preserving forests, cutting down dry trees, etc.

- learning about medicinal herbs and how to gather and dry them

- honey extraction

- processing and smoking meat

- lectures on ecology and organic farming.

These establishments also sell their agricultural products such as wheat, grain, poppy seeds, potatoes, vegetables for storage, as well as fresh vegetables, processed products, yoghurt, cheese, cottage cheese, and whole-grain bread and buns.

\section{Conclusion}

The results of this research identify assumptions for introducing organic food in the gastronomic offering of agritourism in Istria. The results also lead to the conclusion that the tourists surveyed in Istria possess consumer habits linked to the consumption of organic food at home and that they are willing to consume organic food during their stay in Istria as well. Furthermore, it is evident that:

- the organic food offering in Istria is insufficiently developed,

- the level of interest that tourists displayed for organic food does not depend upon their age, and financial standing of tourists,

- organic food is a product in demand with the respondents, and Istria has all the preconditions needed to make organic food its new and distinctive offering.

This entails the need of educating the agritourism providers of Istria with regard to organic food and how to improve their relationships with tourists who are willing to consume organic food. The results obtained can serve as a sound basis for conceiving a marketing approach to creating an acceptable and competitive gastronomic offering in Istria's agritourism.

\section{References}

Arvanitoyannis, I. S., Krystallis, A. (2004). Current state of the art of legislation and marketing trends of organic foods worldwide, in: Baourakis, G. ed. (2004). World Marketing trends for Organic food in the 21st Century. World Scientific, New Jersey, London, Singapure, Shanghai, Hong Kong, Taipei, Bangalore 
Davies, A., Titterington, A.J., Cochrane, C. 1995. Who buys organic food? A profile of the purchasers of organic food in Northern Ireland. British Food Journal 97 (10), 17-23.

Fernandez, P. L., Baquez, M. Y., Matamoros, T. A. 2003. Los alimentos ecologicos, los preferidos de los turistas del siglo XXI. Revista del Jardin Botanoco National 24 (1/2), 23-26.

Radman, M. 2005. Consumer consumption and perception of organic products in Croatia. British food journal 107, 4, 263-273

Squires, L., Juric, B., Cornwell, B. T. 2001. Level of market development and intensity of organic food consumption: cross-cultural study of Danish and New Zealand consumers. Journal of Consumer Marketing 18, 5, 392-409.

www.zemljani.com/forum/viewtopic.php 